\title{
Marisol Álvarez $(1968-2021)^{1}$
}

DOI: http://doi.org.10.18861/ic.2021.16.1.3107

\section{ÁLVARO BUELA}

buela@ort.edu.uy - Catedrático de Realización Cinematográfica, Universidad ORT Uruguay, Uruguay.

\section{in memoriam}

Voy a cometer un acto imprudente: trataré de escribir esta breve semblanza de Marisol Álvarez sin recurrir a ninguno de los autores que habitaban su galaxia intelectual (Nietzsche, Blanchot, Derrida, Foucault, Barthes, Deleuze, Lacan, entre otros) y que bien vendrían al auxilio de este momento, no sólo para adensar la reflexión sino, sobre todo, para ingresar con ellos al territorio del dolor y el vacío. O del dolor por el vacío.

Pero no. Elijo el ensayo de otra vía, seguramente más sinuosa, pero también más justa (ella se reiría de esta quimera) haciendo uso y abuso de la ardua tarea que me ha tocado: evocar la profusión de su(s) saber(es), señalar su lucidez crítica, rescatar la inmensa huella que ha dejado en quienes tuvimos el privilegio de estar a su lado, como colegas, como amigos, como estudiantes.

Detengámonos en éstos últimos, los estudiantes.

En los días posteriores a su fallecimiento (que no su muerte, porque ha logrado trascenderla), el 7 de febrero, decenas de comentarios de estudiantes y ex estudiantes tomaron por asalto las redes sociales, dando testimonio de la transformación radical, subjetiva, que les había producido asistir a sus clases, pero al mismo tiempo aludían a un método pedagógico que integraba la emoción, el humor, la ironía y una insólita capacidad para observar bajo una intensa luz teórica fenómenos en apariencia prosaicos y banales.

No deja de ser una paradoja que ella, que no tenía en cuenta ninguna red social y que aborrecía de la promiscuidad, tan de esta época, entre lo privado y lo público, se haya convertido, aunque sea por unas horas, en trending topic. Tampoco que muchos de esos comentarios admirativos e, incluso, amorosos de sus ex estudiantes aludieran a una suerte de anagnórisis, de ruptura, de choque, algo que, por obra y gracia de su maestría, no poseía un carácter traumático sino, más bien, el de una revelación.

1 Docente de la Licenciatura en Comunicación de la Universidad ORT Uruguay. Su fallecimiento sorpresivo, en la ciudad de Montevideo (Uruguay), deja un vacío inmenso en quienes la conocieron, aunque la estela de su trabajo intelectual y académico, ligado en buena medida al campo audiovisual, seguirá permeando la curiosidad y el goce reflexivo de sus colegas y los estudiantes. 
Siguiendo a sus admirados Nietzsche, Benjamin o Hannah Arendt, su efecto docente conjugaba la violencia del conocimiento (de los cismas epistemológicos a la pulsión de saber) y el conocimiento de la violencia (de la ideológica y la política a la institucional y la social), sin perder un ápice de efervescencia ni, utilizando un término que se reitera en los posteos estudiantiles, de pasión.

Había perfeccionado una estrategia para ejercer la docencia que era una continuación, o una transposición, de la energía con que absorbía y procesaba objetos culturales, libros, piezas publicitarias, películas, televisión, fútbol (único territorio al que yo no la seguía). No obstante, había algo más: una capacidad altamente sofisticada para manejar la transferencia con sus estudiantes que, a la vez que contagiaba una alegría dionisíaca por el conocimiento -otra vez Nietzsche, pese al propósito inútil de prescindir de él-, era capaz de mantener, invulnerable, un lugar radiante donde conducía los cuestionamientos y las preguntas; nunca el saber congelado.

En ese sentido, es posible designar a esa estrategia como una erótica de la enseñanza, un concepto del psicoanalista italiano Massimo Recalcati (2016) que, francamente, desconozco si había leído (probablemente sí; ella leía todo) y del que tomo una cita para que hable por sí sola:

Al negarse a encarnar el saber, Sócrates remite al discípulo el saber que el discípulo buscaba en él, manteniendo abierta la sede del conocimiento como sede de una carencia estructural. Preguntémonoslo: ¿acaso no es éste el movimiento esencial que caracteriza el trabajo de todo docente digno de tal nombre? Abrir vacíos en las cabezas, abrir agujeros en el discurso ya formado, hacer hueco, abrir las ventanas, las puertas, los ojos, los oídos, el cuerpo, abrir mundos, abrir aperturas no concebidas antes. ¿Acaso no es ésta la materia de la que está hecha la erótica de la enseñanza? ¿No es éste el gesto que trae a la vida una enseñanza capaz degenerar efectos infinitos de subjetivación? ¿No es éste el sentidoúltimo de la transformación de los objetos del saber en cuerpos eróticos que debería poner en práctica toda enseñanza? (p. 54).

"Docente digna de ese nombre", Marisol era también una amiga digna de ese nombre, pero en ese terreno voy a respetar su celo por la privacidad, algo que comparto, y me voy a limitar a evocar aquí una de las últimas conversaciones que tuvimos por teléfono.

Fue en diciembre. Hacía un tiempo que no hablábamos, sumergidos ambos en tareas académicas. La noté algo apagada, pero teníamos un pacto implícito de no hacer interpelaciones a quemarropa, sino dejar que la charla fluyera $y$, recién ahí, entrar en zonas másíntimas. De modo que, luego delosintercambios de rigor -tantos obligatorios para corregir, tantas tutorías de investigación, cómo veíamos estos proyectos, y así- me contó que después de mucho tiempo se estaba haciéndose chequeos médicos.

La felicité por eso, y pasamos al motivo inicial de mi llamada: quería recomendarle un artículo de Slavoj Žižek (2018) sobre Ernst Lubitsch, la censura 
y la corrección política, que había descubierto en la web y que parecía escrito especialmente para ella.

A partir de ahí, su languidez mutó, súbitamente, en entusiasmo. Luego de una exclamación admirativa, muy suya, me pidió más datos para buscarla, en ese mismo momento, y estuvimos largo rato charlando sobre el artículo, la revista que lo había publicado, Žižek y Lubitsch, para luego derivar, como solíamos hacer, en las películas o series que habíamos visto y los libros que habíamos leído. Pero me detengo aquí. La pequeña infidencia es suficiente para ilustrar el punto.

El absurdo periplo médico que soportó en las semanas siguientes, con causas y responsabilidades compartidas entre los protocolos de atención telefónica, las demoras en los resultados de los estudios y la conducta errática de los especialistas, dilató innecesariamente lo que debió ser una intervención quirúrgica menor.

De todo esto nos enteramos a posteriori, ya que era reservada hasta para sus padecimientos. Sobre todo para sus padecimientos. Prefería vincularse desde un vitalismo cuestionador y un cinismo basal, entendido éste según su raíz filosófica, es decir, una suerte de misantropía que mira el mundo con tanto de desconfianza como de piedad y, por momentos, de humor.

Su fallecimiento (que no su muerte, insisto) deja un vacío ensordecedor, pero también nos pasa una posta que nos impulsa a ser mejores. Nos toca a nosotros.

\section{REFERENCIAS}

Recalcati, M. (2016). La hora de clase. Barcelona: Anagrama.

Žižek, S. (2018). Ernst Lubitsch, Censorship, and Political Correctness. American Affairs, 3(2). Recuperado de: https://americanaffairsjournal.org/2018/08/ernstlubitsch-censorship-and-political-correctness

\section{(cc) BY}

Artículo publicado en acceso abierto bajo la Licencia Creative Commons - Attribution 4.0 International (CC BY 4.0) 